\title{
Türkiye'nin Sıhhi ve İçtimai Coğrafyası Eserlerine Göre Verem Hastalığının Seyri
}

\author{
DOI: 10.26466/opus.567455
}

*

\section{Cihat Tanıș*}

* Dr. Öğr. Üyesi, Kırşehir Ahi Evran Üniversitesi, Fen-Edebiyat Fakültesi, Tarih Bölümü,, Kırşehir/ Türkiye

Öz

E-Posta: cihattanis@gmail.com

ORCID: 0000-0002-2000-731X

Tarih boyunca birçok toplumu etkileyen ve çok sayıda ölüme neden olan bulaşıcı hastalıklarla mücadele devletlerin öncelikleri arasında olmuştur. Bu bağlamda başlangıçta Osmanl, sonrasında ise Türkiye Cumhuriyeti Devleti bulaşıcı hastalıklarla daha etkili mücadele edebilmenin yollarını aramıştır. Ancak 20. yüzyılın başlarında Balkan Savaşları ile başlayan ve Türkiye Cumhuriyeti'nin kurulması ile sonuçlanan uzun süreli savaşlar toplumu büyük bir sefalete sürüklemiştir. Yaşanan sefalet beraberinde verem gibi bulaşıcı hastalıklara davetiye çıkarmıştır. Bu nedenle başta TBMM daha sonra Cumhuriyet hükümetleri, bir yandan ülkenin sosyo-ekonomik durumu düzeltmeye çaşıllırken diğer yandan hastane, dispanser ve sanatoryum gibi birçok müsesese açarak veremle mücadele etmeye çalışmıştır. Bunun yan sıra ülke genelini iyi bir şekilde etüt edebilmek amacıyla Türkiye'nin Sihhi ve İçtimai Coğrafyası eserlerini hazırlatmışlardır. Bu eserler eğitim, sağlık, ekonomi, nüfus gibi yazıldıklar bölgeyle önemli bilgiler içermektedir. Bu çalışmada toplamda 15 vilayet incelenmiştir. Böylelikle Türkiye'nin Sihhi ve Iç̧timai Coğrafyası eserlerinden faydalanılarak dönemin toplumunu önemli ölçüde etkileyen verem hastah̆̆ğıın hangi vilayette ne kadar yaygınlıkta görüldü̈̆̈̈ saptanmaya çalışılmıştır.

Anahtar Kelimeler: Verem, Bulaşııı Hastalık, Dispanser. 


\title{
The Course of Tuberculosis Disease Acording to Turkey's Sanitary and Social Geography Works
}

*

\begin{abstract}
It has been among the priorities of states to combat infectious diseases that have affected many societies and caused many deaths throughout history. In this context, the Ottoman initially, then the Republic of Turkey has been looking for ways to be able to more effectively combat infectious diseases. However, the long-term battles that started with the Balkan Wars in the early 20th century and were resulted in the establishment of the Republic of Turkey have led society into great misery. The experienced misery has issued along with an invitation to infectious diseases such as tuberculosis. Therefore, the first Grand National Assembly of Turkey and then the government of the Republic tried to improve the socio-economic situation of the country on the one hand while trying to fight against tuberculosis by opening up a lot of offers such as hospitals, dispensaries and sanatoriums. These works provide information on many subjects from education to health about the region in which they are written. In this study, it has been aimed to determine how widespread tuberculosis disease, which significantly affects the population of the period, was seen in which province by being benefited from Turkey's Sanitary and Social Geography Works.
\end{abstract}

Keywords: Tuberculosis, Contagion, Dispensary 


\section{Giriş}

Bulaşıcı hastalıkların tarihte birçok toplumu yok olma eşiğine getirmiş olması, toplumları sosyo-ekonomik ve askeri bakımdan derinden etkilemiştir (Yavuz, 2017, s.226). Ortaya çıkmalarında iklim, ekonomik koşullar ve temizlik alışkanlıkları etkili olmuştur (Kardaş, 2010, s.15). Tarih boyunca verem, sitma, veba ve kolera gibi bulaşıcı hastalıklar en yaygın görülen illetlerin başında gelmiştir (Kumaş, 2011, s.213).

Osmanlı Devleti'nde 19. yüzyılda farklı hastalıklar nedeniyle birçok bulaşıcı hastalık ortaya çıkmıştır. Yaşanan hastalıklar sonucunda sayısız insan hayatını kaybetmiştir. Bunların en ölümcül olanı şüphesiz veba ve koleradır. Ardından verem ve sitma gelmektedir. 19. yüzyılın ikinci yarısından itibaren Anadolu'ya farklı coğrafi bölgelerden çok sayıda insanın göç etmesi ile birlikte bulaşıcı hastalıklarda artış yaşanmıştır. Osmanlı Devleti, Tanzimat'tan Cumhuriyet'in ilanına kadar geçen sürede bulaşıcı hastalıklara karşı çeşitli önlemler alarak mücadele etmiştir. Bunların başında temel koruyucu tedbirler ve karantina uygulamaları gelmiştir. Benzer durum Cumhuriyet'in ilk yıllarında da görülmüştür. Bu yıllarda bir yandan sağlık kurumları oluşturulmaya çalışılırken diğer yandan ülke nüfusunu hızlı bir şekilde tahrip etmekte olan verem gibi hastalıklarla mücadele edilmiştir (Doğan, 2017, s.598).

Modern tıptan önce bulaşıcı hastalıkların birçoğu hekimlerin hastalıklarla ilgili bilgilerin az olması nedeniyle veba olarak adlandırılmıştır (Kılıç, 2004, s.14). Bu nedenle veremin de dâhil olduğu birçok hastalık uzun yıllar teşhis edilemediği için tedavi yöntemi de geliştirilememiştir. Ancak Dr. Robert Koch'un 19. yüzyılda veremi bilimsel olarak teşhis etmesiyle beraber hastalığın tedavi usullerinde gelişim sağlanmıştır. Türk insanını büyük oranda verem, Myobacterium Tuberculosis veya verem basili denilen organizmanın yol açtığı ölümcül, bulaşıcı bir hastalıktır. Mikrop doğrudan akciğerleri hedef alır. Akciğerlerin delinmesi kanamalara sebep olur ve balgam kanlanır. Hastaların doktora ilk gidiş nedeni genellikle kan tükürmeleridir (Kara, 2008, s.87). Kısa sürede kişinin bünyesinde ortaya çıkmayabilir. Hastalık belirtilerinin ortaya çıkması ayları hatta bazen yılları bulabilmektedir. Bu nedenle veremin seyri, kişinin bünyesine göre değişiklik göstermektedir (Barış, 2003, s.1). 
Verem, gerek Osmanlı döneminde gerekse de Cumhuriyet'in ilk yıllarında oldukça yaygındır. Bu nedenle özellikle Cumhuriyet döneminde hastalığı azaltabilmek amacıyla birçok çalışma yapılmıştır. Bunların en başında dispanser ve sanatoryumlar açmak gelmiştir. Ancak bu tür kurumların açlabilmesi için ülkenin içinde bulunduğu şartların etüt edilmesi gerekiyordu. Bu amaçla hazırlanan Türkiye'nin Sihhi ve İçtimai Coğrafyası adlı eserler oldukça mühim çalışmalardır. Bu eserlerde etüt ettikleri bölgelerle ilgili birçok husus ele alınmıştır. Ancak bu çalışmada Türkiye'nin Sıhhi ve İçtimai Coğrafyası eserleri ekseninde ülke genelinde veremin yaygınlığ 1 tespit edilmeye çalışılmıştır.

\section{Cumhuriyetin İlk Yıllarında Verem ile Mücadele}

Toplum sağlığını tehdit eden bulaşıcı hastalıklara karşı modern anlamda mücadele Sağlık Bakanlığı'nın kurulmasıyla beraber daha etkin bir hâl almıştır. Özellikle 1930 yılında kabul edilen Umumi Hıfzıssıhha Kanunu ile birlikte bulaşıcı hastalıklarla mücadelenin yöntemleri yeniden saptanmış ve daha hızlı hareket edebilmek amacıyla aşı ve serumların hükümet tarafından hazırlanmasına karar verilmiştir (Tekin, 2011, s.51). Ayrıca verem savaş ile ilgili ilk dernek 1918'de İstanbul'da açılan Veremle Mücadele Osmanlı Cemiyeti olmuştur. Ancak Cemiyet, uzun süre faaliyet gösterememiş ve İstanbul'un İtilaf devletleri tarafından işgali üzerine kapanmak zorunda kalmıştır. Aktif olduğu kısa sürede vereme karşı gazete, afiş ve broşür yoluyla halkı bilinçlendirmeye çalışmıştır (Doğan, 2017, s.601).

Verem savaş ile ilgili ikinci dernek 1923 yılında İzmir' de Dr. Behçet Uz tarafından kurulan İzmir Veremle Mücadele Cemiyeti olmuştur. Bu Cemiyet, Osmanlı döneminde kurulan, ancak İstanbul'un işgali nedeniyle işlevsiz kalan Veremle Mücadele Osmanlı Cemiyeti'nin mirasına sahip çıkmıştır (Gürgan, 2013, s.140-141). Daha sonra başta Balıkesir olmak üzere birçok kentte verem savaş dernekleri kurulmuştur (Coşkun, 2017, s.4).

Verem savaşta önemli yeri olan dispanserlerin açılma düşüncesi Veremle Mücadele Osmanlı Cemiyeti'nin bir toplantısında dile getirilmiştir. Fakat ilk dispanserler ancak 1923 yılında İstanbul'da İl Özel İdaresi bünyesinde hizmete girebilmiştir. Akabinde İzmir'de 1929 yılında İzmir Verem Savaşı Derneği tarafından dispanser binasının yapımına 
başlanmıştır (Gürgan, 2013, s.140). İlk müstakil dispanser ise 1928 yılında İstanbul'un Eyüp ilçesinde açılmıştır. Bunun yanı sıra Ankara ve Bursa verem savaş dispanserleri 1930 yılında, Trabzon verem savaş dispanseri ise 1935 yılında açılmıştır (Tekin, 2011, s.59). II. Dünya Savaşı yıllarında veremin toplumda tehlikeli boyutlara çıması neticesinde İstanbul'da bazı dispanserler açılmıştır. Buna göre, 1941'de Beykoz'da, 1943'te Üsküdar, Unkapanı ve Şehremini'nde, 1945'te Kasımpaşa ve Edirnekapı'da olmak üzere, altı dispanser daha faaliyete geçmiştir (Çakırçoban, 2010, s.110, 112).

Veremle mücadele çoğunlukla dispanserler vasıtasıyla yapılmıştır. Bunun yanı sıra sanatoryumlar ile de tedavi desteklenmiştir. Bu amaçla 1924 yılında Sağlık Bakanlığınca İstanbul Heybeliada'da 50 yataklı bir Verem Sanatoryumu açılmış olup yanı sıra İstanbul'daki Emraz-ı Sâriye Hastanesi'nde 50, İzmir'deki Emraz-ı Sâriye Hastanesi'nde ise 25 yatak verem hastalarına tahsis edilmiştir (Tekin, 2011, s.51). 1930 yılında Heybeliada'daki sanatoryuma 35 yataklı bir bölüm daha ilave edilerek yatak sayısı 130'a çıkarılmıştır. Haydarpaşa'daki Bulaşıcı Hastalıklar Hastanesi'ndeki veremlilere ayrılan yatak sayısı da 75'e çıkarılmıştır (Karabulut, 2007, s.158).

Türkiye'de veremden etkilenen vatandaşların arasında zengin fakir ayırt etmeksizin birçok kesimin olması durumun vahametini ortaya çıkarmaktadır. Özellikle belli gelir seviyesindeki insanlar arasında sirayet etmesi deyim yerindeyse onu fakir hastalığı olmaktan çıkarıp toplumun geneli için bir tehdit oluşturmuştur. Bütün bu sebepler nedeniyle toplu yaşam alanlarında gerekli olan hijyen için hassasiyet gösterilmesine çalışılmıştır (Tuğluoğlu, 2008, s.16,20).

Yukarıda sayılanlara ek olarak verem gibi bulaşıcı hastalıklar ile daha etkin şekilde mücadele edebilmek amacıyla 17 Mayıs 1928'de Umumi Hıfzıssıhha Kurumu kurulmasına dair kanun çıkarılmış ve bu bağlamda Sivas ve Ankara'daki kimyahaneler birleştirilerek Hifzıssıhha Kurumu oluşturulmuştur (Tükel, 2010, s. 10). Ayrıca Türk Milli Tip Kongrelerinin ilk üçü, özellikle bulaşıcı hastalıklarla mücadele üzerinde durmuştur. Bu bağlamda Türk Milli Tıp Kongrelerinin ilki 1-3 Eylül 1925'te yapılmış, sitma ve verem tedavisi ve mücadelesi ana gündem maddelerini oluşturmuştur. 11-13 Eylül 1927'de yapılan II. Milli Tıp Kongresi'nde ise öncelikle 
trahom ve verem tedavisi konuşulmuştur. (Özkaya, 2016, s.120-122, 126127).

\section{Tarihi Bir Kaynak Olarak Türkiye'nin Sıhhi ve İçtimai Coğrafyası Eser- leri}

20. yüzyılın başlarında Balkan Savaşları ile başlayan uzun bir savaş dönemi, I. Dünya Savaşı ve son olarak İstiklal Savaşı ile sonuçlanmıştır. Yaklaşık 10 yıl süren bu savaşlar Türkiye'de, kıtlık, yoksulluk, bulaşıcı hastalıklara davet çıkarmıştır. Bu durum elbette en çok sıhhi durumu kötüleştirmiştir. Bu nedenle 1920 yılında TBMM Hükümeti hem kısa vadede sağlık sorunlarına çözüm bulmaya hem de gelecekteki sağlık politikalarını belirlemek amacıyla yukarıda da bahsedildiği gibi ilk iş olarak 20 Mayıs 1920 tarihinde kabul edilen üç numaralı kanun ile Umur-ı Sıhhiye-i Muavenet-i Içtimaiye Vekâleti yani Sağlık Bakanlığı'nı kurmuştur (Doğruöz, 2011, s. 276).

Sağlık Bakanlığı'nın kurulmasıyla başına Dr. Adnan (Adıvar) Bey getirilmiştir. Onun döneminde teşkilatlanma ve mevzuat eksikliklerinin giderilmesine ağırlık verilmiştir. Bir sonraki bakan Dr. Refik (Saydam) Bey döneminde söz konusu salgın hastalıklarla mücadele edebilmek için Türkiye'nin birçok şehrinin etüt edilmesinin gerekliliğine inanılmış, bu kapsamda il sağlık teşkilatlarından, bulundukları yöreleri coğrafi, sosyolojik ve sıhhi koşullar açısından incelemeleri ve ulaştıkları sonuçları vekâlete rapor etmeleri istenmiştir. Dr. Refik (Saydam) Bey'den görevi devralan Dr. Rıza Nur döneminde de bu eserler tasnif edilerek bir dizi halinde yayınlanmıştır (Esen, 2017, s. 78).

Belirli bir plan dâhilinde ilgili vilayetlerde yapılan araştırmalar sonucunda hazırlanan eserlerde, sağlıkla ilgili bilgilerin dışında, vilayetlerin coğrafya, idari yapı, folklor, nüfus, eğitim, tarım, ekonomi, hayvancılık açısından durumları değerlendirilmiştir (Doğruöz, 2011, s. 276). Toplamda 19 eserden oluşan dizinin ilk kitabı 1922 yılında yayınlanan Türkiye'nin Sihhi ve İçtimai Coğrafyası Sinop Sancă̆̆, sonuncusu ise 1938 yılında yayınlanan Tokat Vilayeti Sıhhi ve İçtimai Coğrafyası olmuştur. Kıymetli bilgilerin yer aldığı bu eserlerdeki salgın hastalıklar ile ilgili bölümler, o dönemki sıhhi koşullara ilişkin fikir edinmek açısından önemlidir (Esen, 2017, s. 78). Bu çalışma kapsamında ise 15 vilayette ile ilgili 
kısımlar bulunup Cumhuriyetin ilk yıllarında Anadolu'da veremin ne oranda yaygın olduğu tespit edilmeye çalışılmıştır.

\section{Vilayetlere Göre Verem Hastalığı}

\section{Ankara}

Vilayetin birçok noktasında hastalığa yakalananlarının olduğu, özellikle bataklık olan bölgelerde sitma ile birleşmesi nedeniyle daha fazla görüldügü belirtilmiştir. Buna bölge insanın bilinçsizliği eklenince verem vilayette deyim yerindeyse kol gezmiştir. Eserde verem benzeri bulaşıcı hastalıklardan korunmanın en önemli yolunun hijyene dikkat etmek olduğunu söyleyen yazar Muhittin Saffet Bey, Ankara vilayetinde buna pek riayet edilmediğini belirtmiştir. Hatta ona göre, hastalıklı insanlar balgamlı mendillerini evin her köşesine atmaktadırlar. Nitekim bu tespitler mübalağalı olsa da hijyen eksikliği olduğu ortadadır. Son olarak Muhittin Saffet Bey, verem ile mücadele edebilmek amacıyla bilinçsizliğin önlemesi gerektiği ve bu kapsamda ufak risaleler basılıp ahaliye ücretsiz dağıtılması önerisinde bulunmuştur (Saffet, 1925, s. 102; Esen, 2017, s.84).

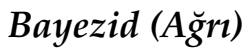

Vilayette verem hastalığı oldukça az görülmektedir. Hastalığın bölgede az görülmesinin en önemli nedeni yaşanılan doğal ortam yani temiz hava ve su gösterilmiştir (Ethem, 1925, s.28).

\section{Çatalca}

Çatalca'da verem oldukça yaygındır. Mehmet Ali Bey'e göre bunun en önemli sebebi fakirliktir. Ayrıca bölgedeki evlerin yeterince sıhhi ve korunaklı olmaması da veremi tetiklemiştir. Ona göre; Balkan muhacirlerinin yaşadıkları evlerin üst katlarında keçi koyun beslemeleri ve evlerin pencerelerinin küçük olması nedeniyle güneş alamaması hastalığı alevlendirmiştir. Bunun yanı sıra kırsal kesimde yaşayan ahalinin önemli 
bir kısmının yemeklerini yattıkları odada yapıp yemeleri ve evin tuvaletinin oldukça ilkel bir halde olup sıhhi olmaması gibi sebeplerden dolayı verem bölgede yaygın olarak görülmüştür (Mehmet Ali, 1925, s.45-46).

\section{Çankırı}

Çankırı'da verem hastalığının çok az seyrettiği belirtilmiştir (Esen,2017, s.87).

\section{Gelibolu}

Vilayet merkezinde ve Enez'de hastalıklı insan sayısı fazladır. Buna karşılık İpsala ve Keşan'da daha az rastlanmaktadır. Özellikle Gelibolu taraflarının sert ve rüzgârlı havasının vereme iyi gelmediği belirtilmiş ve son olarak fakirliğin hastalığı tetiklediği vurgulanmıştır (Fahri Cemal, 1925, s.33).

\section{Isparta}

Isparta'da verem vakası fazla değildir. Ancak bölge insanının fakirliği nedeniyle az da olsa göründüğü belirtilmiştir (Besim Zühdi, 1922, s.44).

\section{Kastamonu}

Verem hastalığının Kastamonu'da görüldüğgünü belirten Dr. Kemal Bey, bu hastalıkla sıhhi olarak mücadeleden daha çok Maarif ve İktisat Vekâletleri' nin mücadele etmesi gerektiği teklifinde bulunmuştur (Kemal, 1922, s.46). Dr. Kemal Bey'in amacı muhtemelen bu yolla fakirliği azaltıp, halkı bilinçlendirerek veremi kendiliğinden azaltma düşüncesidir.

\section{Kayseri}

Kayseri'de verem hastalığının seyrinin az olduğu belirtilmiştir (Hıfzı Nuri, 1922, s. 42). 


\section{Kırklareli}

Ilıman bir iklime sahip olması nedeniyle verem vilayette nadiren görülen hastalıklar arasında sayılmıştır (Ahmet Hamdi, 1925, s.43).

\section{Kırşehir}

Verem, Kırşehir'de tehlike arz edecek kadar yaygın değildir. Ayrıca cilt, kemik ve lenf veremlerine rastlandığı belirtilmiştir (İbrahim İsmail, 1925, s. 51; Esen, 2017, s. 86).

\section{Konya}

Dr. Nazmi Bey'in hazırladığı çalışmaya göre, Konya genelinde önemsenecek düzeyde veremli hasta bulunmamaktadır. Bununla birlikte Ereğli Kazasında ahalinin hıfzıssıhha kurallarına riayet etmemesinden kaynaklı veremli hasta vakası daha fazladır. Hastalığın az seyrettiğinin en önemli kanıtı Seydişehir Kazasının ovalık kesimlerinde iki sene zarfında 10, dağlık kesimlerinde ise beş olmak üzere toplam 15 verem vakasına rastlanmış olmasıdır. Yine Bozkır Kazasında üç sene zarfında üç kişi vefat etmiştir. Beyşehir'de ise benzer şekilde nadiren verem hastalı̆̆ının görüldüğü Dr. Nazmi Bey tarafından belirtilmiştir (Nazmi, 1922, s. 83; Esen, 2017, s. 83).

\section{Muğla}

Muğla şehir merkezinde hastalığa az rastlandığı belirtilirken daha çok kasaba ve köylerde görüldügü vurgulanmıştır. Ancak köylerdeki zayıf bünyeli insanların gerek doğal ortam gerekse bol güneş sayesinde hastalığa karşı mukavemet edebildikleri ve Muğla'nın coğrafyası ve iklimi itibariyle sanatoryum inşasına oldukça uygun olduğu belirtilmiştir (Esat, 1922, s. 88). 


\section{Niğde}

Yaşanılan mekânların hıfzıssıhhaya aykırılıkları ve sefalet gibi nedenlerin yanı sıra, halıcılık, bezcilik gibi zanaatların kötü çalışma koşullarında yapılması veremin vilayette sık görülme nedenlerinden sayılmıştır. Ayrıca düğün gibi önemli günlerde emanet olarak giyilen elbiseler sebebiyle hastalık insanlar arasında yayılmıştır. Bu bağlamda hijyen kuralları ile bağdaşmayan örf ve adetler hastalığın yayılmasını kolaylaştırmıştır. Mevcut koşullarda yapılabilecek yegâne tedbir kullanılmış elbise ve eşyanın tekrardan satılmasına mani olmak ve veremli hastaların yaşadığ 1 evlerdeki eşyaların temizliğine dikkat edilmesi hususunda ahaliyi uyarmak olarak görülmüştür (Mehmet Hayri, 1922, s. 178; Esen, 2017, s.81).

\section{Sinop}

Mehmet Said Bey'in tespitlerine göre, hastalık daha çok Sinop merkez, Gerze, Ayancık ve bunlara bağlı köylerde fakirlik dolayı yaygın olarak görülmüştür. Mehmet Said Bey, bu eseri hazırladığı 1922 yılına kadar vilayette verem ile mücadele hususunda herhangi ciddi girişimde bulunulmadığını, ayrıca Men-i Müskirat Kanunu'nun sıkı bir şekilde tatbikinin verem gibi bulaşıcı hastalıklarla mücadelede önemli olduğunu belirtmiştir (Mehmet Said, 1922, s. 60).

\section{Urfa}

Şefik Bey'e göre verem, Urfa'da ekseriyetle kasabalardaki kadınlar arasında görülmüş olup köylerde nispeten daha azdır. Bölge halkının gidasız kalmasının yanı sıra ve sıhhi olmayan meskenlerde ikamet etmesi hastalığ1 tetiklemiştir. Başka vilayetlerde olduğu gibi bazı örf ve adetlerinde veremin yayılmasında payı vardır (Şefik Arif, 1925, s.39). 


\section{Sonuç}

Verem, binlerce yıllık bir tarihe dayanan ve çok sayıda insanın ölümüne yol açmış bulaşıcı bir hastalıktır. Hastalığa neden olan basilin bulunmasının ardından tedavi yöntemleri giderek gelişmiş olmasına rağmen 20. yüzyılın başlarında dahi Türkiye'deki ölümcül hastalıkların başında gelmiştir. Özellikle Balkan Savaşları ile başlayıp I. Dünya Savaşı ve İstiklal Savaşı ile sonlanan uzun yıllar toplumun önemli bir kesimini sefalet içerisinde bırakmıştır. Bu durum yeni kurulan Türkiye Cumhuriyeti'ni vereme karşı daha aktif bir sağlık politikası uygulamaya itmiştir. Bu amaçla veremle savaş cemiyetleri, dispanserler ve sanatoryumlar açılmış ve bu vasıtayla veremle mücadele edilmiştir. Bunların yanı sıra toplumun içinde bulunduğu durumu daha net bir şekilde ortaya koyabilmek amacıyla Sıhhiye Vekaleti'nin talimatıyla Türkiye'nin Sıhhi ve İçtimai Coğrafyası adlı eserleri hazırlanmıştır. Türkiye'nin her bölgesinden 15 şehrin incelendiği bu çalışmada verem az da olsa her şehirde görülen ve en fazla ölüme yol açan bulaşıcı hastalıklardan biri olmuştur.

Veremin bu kadar yaygın olmasında yukarıda bahsedildiği üzere hayat şartlarının kötü olması, mesken durumu, çevre sağlığı ve gıda yetersizliği gibi sosyal faktörler oldukça etkili olmuştur. Vereme karşı nasıl tedbirler alınması gerektiği hususu da eserlerde belirtilmiştir. Netice itibariyle Türkiye'nin Sıhhi ve İçtimai Coğrafyası adlı çalışmalar Cumhuriyetin ilk yıllarında Türkiye' nin detaylı etüdünün yapıldığı ve çalışmanın konusu olan verem vakasının nasıl seyrettiğini gözler önüne sermesi açısından oldukça önemli eserlerdir. 


\title{
EXTENDED ABSTRACT
}

\section{The Course of Tuberculosis Disease Acording to Turkey's Sanitary and Social Geography Works.}

\author{
Cihat Tanış \\ KırşehirAhi Evran University
}

Infectious diseases have brought many societies to the brink of extinction. Climate, economic conditions and hygiene are effective in their emergence. In the 19th century, countless people died in Anatolia due to infectious diseases. The most deadly ones were plague, cholera and tuberculosis. Migration to Anatolia after military defeats has been effective in the spread of these diseases. Therefore, various measures have been taken against infectious diseases. The main protective measures and quarantine practices are the main ones. In the early years of the Republic, many health institutions were opened to those who existed. In this way, infectious diseases such as tuberculosis have been fought. Tuberculosis, a deadly infectious disease, directly targets the lungs. Bleeding of the lungs causes bleeding. Disease symptoms may not occur in a short time. Thus, the progression of tuberculosis disease varies from person to person.

The war period, which started with the Balkan Wars in the early 20th century, finally resulted in the War of Independence. These wars lasted for about 10 years, caused the rise of famine, poverty and infectious diseases in Turkey. This situation, of course, has aggravated the health situation the most. The Turkish Grand National Assembly established the Ministry of Health in 1920 as the first task in order to improve the health situation quickly. The modern struggle against infectious diseases threatening public health has become more effective with the establishment of the Ministry of Health. The methods of combating infectious diseases were determined together with the General Public Health Law, which was adopted in 1930. In addition, it was decided that the vaccine and serums were prepared by the Government in order to be able to move faster.

The first association of tuberculosis war was the Ottoman Society of Fighting against Population in Istanbul in 1918. However, the Society was 
forced to close on the occupation of Istanbul by the Allied Powers. Although it was active in a short time, it tried to raise public awareness through newspapers, posters and brochures against tuberculosis. The second association of Verem War was established in 1923 by Dr. Behcet Uz in Izmir, Izmir Tuberculosis Society. Then, in many cities, especially Balikesir, tuberculosis war associations were established. The most important aim of these associations was to enlighten the public against tuberculosis. The idea of installation dispensaries, which had an important place in the fight against tuberculosis, was mentioned at a meeting of the Ottoman Society. However, the first dispensaries were put into service in 1923 under the Special Provincial Administration in Istanbul. Subsequently, construction of the dispenser building was started in Izmir in 1929 by Izmir tuberculosis War Association. The first independent dispensary was opened in 1928 in Eyup, Istanbul. Ankara and Bursa tuberculosis dispensaries were opened in 1930 and Trabzon tuberculosis dispensary was opened in 1935. Some dispensaries were opened in Istanbul as a result of the emergence of tuberculosis to dangerous dimensions in the society during World War II. According to this, six dispensaries were established in Beykoz in 1941, in Uskudar, Unkapani and Sehremini in 1943 and in Kasımpasa and Edirnekapi in 1945. In addition to these, treatment with the sanatorium was supported. For this purpose, a tuberculosis sanatorium with 50 beds was opened in Istanbul Heybeliada by Ministry of Health in 1924. In addition, 50 beds were allocated to the patients at Emraz-1 Sariye Hospital in Istanbul and 25 beds were allocated to the patients at Emraz-1 Sariye Hospital in Izmir. In 1930, a further 35 beds were added to the sanatorium at Heybeliada and the number of beds was increased to 130. The number of beds allocated to tuberculosis in Haydarpasa Hospital was increased to 75.

Minister of Health in Adnan (Adıvar) Bey period, organization and the elimination of deficiencies were emphasized. Then, during the period of Dr. Refik (Saydam) Bey, it was believed that the necessity of studying many of Turkey's city was to be able to fight infectious diseases Prepared for this purpose "The Works of Turkey's Sanitary and Social Geography " are quite important work. These works have dealt with many issues related to the areas of study. In these works, which are prepared as a result of research in the relevant provinces within a certain plan, the state of the 
provinces in terms of geographical, administrative structure, folklore, population, education, agriculture, economy, livestock, other than healthrelated information Evaluated. The first book of this series of 19 works was published in 1922, titled "Turkey's Sanitary and Social Geography Sinop Province", and the last one titled "Tokat Province Sanitary and Social Geography", which was published in 1938. The sections related to infectious diseases in these works, which contain important information, are important to get an idea of the sanitary conditions at that time. Within the scope of this study, 15 provinces were examined and it was found that the first years of the Republic, tuberculosis was observed in Anatolia in a widespread way.

Social factors such as poor living conditions, housing status, environmental health and food insufficiency have been very effective in the widespread of tuberculosis. In addition, personal hygiene, customs and customs are the determinants of the spread of the disease. As it is understood from the works, the lack of the necessary health infrastructure throughout the country made the treatment of the disease difficult. For this reason, the authors did not neglect to mention how to take precautions against tuberculosis. In conclusion, in his works titled " Turkey's Sanitary and Social Geography ", it was tried to find out how tuberculosis was observed in Turkey in the early years of the Republic.

\section{Kaynakça / References}

Ahmet Hamdi (1925). Türkiye'nin sihhi ve içtimai coğrafyası: Kırklareli vilayeti. İstanbul: Kâğıtçılık ve Matbaacılık Anonim Şirketi.

Barış, İ. (2003). Çağlar boyu tüberküloz. 21. Yüzyılda Tüberküloz Sempozyumu ve II. Tüberküloz Laboratuvar Tanı Yöntemleri Kursu Ders notu. Samsun.

Çakirçoban, İ. (2010). İkinci dünya savaşı'nda Türkiye'de bulaşıcı hastalıklarla mücadele. Yayınlanmamış Yüksek Lisans Tezi, Marmara Üniversitesi Türkiyat Araştırmaları Enstitüsü , İstanbul.

Coşkun, A. (2017). Veremle mücadelede dispanserler, sanatoryumlar ve göğ̈̈s hastalıkları hastaneleri. Yayınlanmamış Yüksek Lisans Tezi, Cumhuriyet Üniversitesi Sosyal Bilimler Enstitüsü, Sivas. 
Doğan, H. (2017). Vefayata mahsus vukuat defterlerine göre salgın hastalıklardan ölümler: Adıyaman örneği. 21. Yüzyılda Eğitim ve Toplum, 6(18), 597-615.

Doğruöz, T. (2011). Kırklareli tarihine 1şık tutacak bir eser: Türkiye'nin sıhhi, içtimai coğrafyası, Kırklareli vilayeti. History Studies, 3(1), s. 275-284.

Doktor Esat. (1922). Türkiye'nin sıhhi ve içtimai coğrafyası:Muğla. Ankara: Okud Matbaasi.

Doktor Kemal. (1922). Türkiye'nin sıhhi ve içtimai coğrafyast:Kastamonu vilayeti. Ankara: Okud Matbaası.

Doktor Nazmi. (1922). Türkiye'nin sıhhi ve içtimai coğrafyası: Muğla vilayeti. Ankara: Okud Matbaası.

Esen, A. (2017). Sıhhi içtimai coğrafya kitaplarına göre iç anadolu'da görülen salgin hastalıklar:1922-1926. Ankara Üniversitesi Türk İnkllâp Tarihi Enstitüsü Atatürk Yolu Dergisi, 60, 73-90.

Fahri Cemal. (1925). Türkiye'nin sihhi ve îçtimai coğrafyast: Gelibolu vilayeti. İstanbul: Kâğıtçılık ve Matbaacılık Anonim Şirketi.

Gürgan, M. (2013). Cumhuriyetin ilk yıllarında İzmir veremle mücadele cemiyeti'nin propaganda faaliyetleri. İzmir Göğüs Hastanesi Dergisi, 27(2), 139-144.

Hıfzı Nuri. (1922). Türkiye'nin sıhhi ve içtimai coğrafyası: Kayseri vilayeti. Ankara: Okud Matbaası.

İbrahim Ethem. (1925). Türkiye'nin sıhhi ve içtimai coğrafyası: Beyazid vilayeti, İstanbul: Kâğıtçllık ve Matbaacılık Anonim Şirketi.

İbrahim İsmail. (1925). Türkiye'nin sıhhi ve içtimai cŏ̆rafyası:Kırşehir vilayeti, İstanbul: Kâğıtçlık ve Matbaacılık Anonim Şirketi.

Kara, M. (2008). XI. ve XIV. yüzyllarda anadolu ve civar bölgelerde hastaliklar. Yayınlanmamış Yüksek Lisans Tezi, Marmara Üniversitesi Türkiyat Araştırmaları Enstitüsü, İstanbul.

Karabulut, U. (2007). Cumhuriyetin ilk yıllarında sağlık hizmetlerine toplu bir bakış: Dr. Refik Saydam'ın Sağlık Bakanlığı ve hizmetleri (1925-1937). ÇITAD, 6(15), 151-160.

Kardaş, T. (2010). XIX. yüzyılda Kafkasya'da salgin hastalıklar ve karantina önlemleri (1800-1900), Yayınlanmamış Yüksek Lisans Tezi, Ege Üniversitesi Sosyal Bilimler Enstitüsü, İzmir. 
Kılıç, O. (2004). Genel hatlarıla dünyada ve Osmanlı devleti'nde salgın hastalıklar. Elazığ: Fırat Üniversitesi Rektörlüğü Orta Doğu Araştırmaları Yayınları.

Kumaş, N. (2011). Bursa'da kolera salgını ve alınan karantina önlemleri: (1890-1895). U.Ü. Fen-Edebiyat Fakültesi Sosyal Bilimler Dergisi, 21, 213-241.

Mehmet Ali. (1925). Türkiye'nin sihhi içtimai coğrafyası:Çatalca vilayeti, İstanbul:Kâğıtçılık ve Matbaacılık Anonim Şirketi

Mehmet Hayri. (1922). Türkiye'nin sıhhi ve içtimai coğrafyası:Niğde sancă̆ı, Ankara: Okud Matbaası.

Mehmet Said. (1922). Türkiye'nin sihhi ve içtimai coğrafyasi: Sinop vilayeti, Ankara: Okud Matbaası.

Muslihiddin Saffet. (1925). Türkiye'nin sihhi ve içtimai coğrafyası: Ankara vilayeti. İstanbul: Hilal Matbaas1,

Şefik Arif. (1925). Türkiye'nin sıhhi ve içtimai coğrafyası:Urfa vilayeti, İstanbul:Kâğıtçılık ve Matbaacılık Anonim Şirketi,

Tekin, G. (2011). Sihhiye ve muavenet-i içtimaiye vekaletinden sağlık bakanlığı'na (1920-2000). Yayınlanmamış Doktora Tezi, Ankara Üniversitesi Türk İnkılap Tarihi Enstitüsü, Ankara.

Tuğluoğlu, F. (2008). Cumhuriyetin ilk döneminde verem mücadelesi ve propaganda faaliyetleri. Yakın Dönem Türkiye Araştırmaları, 13-14, $1-26$.

Tükel, B.(2010). Sağllk sorunları çerçevesinde Milli Türk Tıp kongreleri: 19381958. Yayımlanmamış Yüksek Lisans Tezi, Ankara Üniversitesi Türk inkılap Tarihi Enstitüsü, Ankara.

Yavuz, E. (2017). Ahlat kazasından frengi (XIX. YY. Sonu-XX. YY. Başı), Turkish Studies, 12(26), 223-236.

Zühdi, B. (1922). Türkiye'nin sıhhi ve içtimai coğrafyast:Isparta sancă̆̆. Ankara: Okud Matbaası. 


\section{Kaynakça Bilgisi / Citation Information}

Tanış, C. (2019). Türkiye'nin sıhhi ve içtimai coğrafyası çalışmalarına göre verem hastalığının seyri. OPUS-Uluslararası Toplum Araştırmaları Dergisi, 11(18), 2830-2846. DOI: 10.26466/opus.567455 